(昭和 34 年 11 月 10 日受理)

叨解処理によりパルプから溶出した多糖類について (立)

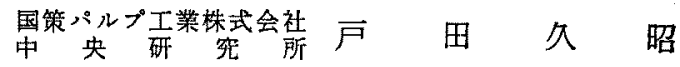

\title{
ON THE POLYSACCARIDES EXTRACTED FROM PULPS BY BEATING
}

\section{By Hisaaki Toda}

(The Research Laboratory of the Kokusaku Pulp Industry Co. Ltd., Kami-Ochiai, Shinjuku-Ku, Tokyo, Japan)

In determination of alkali solubilities of beaten birch bleached sulphite pulp (see Fig. 1 and 2), it has been found that the $10 \% \mathrm{NaOH}$ solubility tends to increase with the progrese of beating, but the $0.5,1,5$ and $18 \% \mathrm{NaOH}$ solubilities tend to decrease (see Fig. 3). The amount of glucan in $10 \% \mathrm{HaOH}$ soluble substances increass by beating, while the amount of xylan, mannan and uronic residues remains nearly constant (see Table 1 ).

By analysis of soluble substance extracted by beating, it is found that methylglucuronoxylan is extracted from the pulp by beating (see Table 2).

In the case of beating of birch holocellulose, small amount of polysaccharides composed of rhamnose-, arabinose-, galactose-, mannose- and glucose-residues are extracted in addition to methylglucuronoxylan (see Table 4). Xylan extracted from the pulp and holocellulose is very rich in uronic acid, and the ratio of uronic units to xylose is $1: 13$ and $1: 7-9$, respectively., whereas the ratio in the xylan of birch bleached sulphite pulp and holocellulose $1: 23$ and $1: 12$, respectively, (see Table 3 ).

Although fir (Abies Mayriana) bleached sulphite pulp contains larger amount of glucomannan (see Table 5), only methylglucuronoxylan is extracted from the pulp by beating (see Table 6).

(Received November, 10, 1959)

\section{I. 緒言}

パルプの諸性質におよぼすパルプ中の人ミせルロース の役割を研究する際には，パルプ中の全へミせルロース 含量 ${ }^{1 \sim 3)}$ ，无いはキシラン，マンナンなどの各多精類 を分別定量し4，あるいはパルプ中のアルカリ溶解物の 量扣よび組成などを測定しで,5)，これらの関係を求め ている。しかし，殊に製紙用パルプの場合には，単に一 ミせルロースの含有量岕るいは人ミセルロースそれ自体

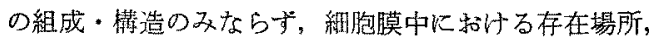
重合度, 女るいはその时の緎維の形状などによつても,

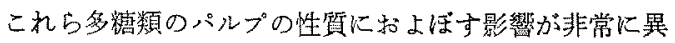
るものと考えられる。

実際に製紙用パルプの場台には吒解処理によつてフィ ブリル化が促進され，それに従つて細胞内の非晶部分に ある多糖類の反応性が增し，これがン゚ルプの抄緍性に大 きな影響をもたらするのと考えられている6。るしこの 際に，低濃度アルカリむるいは他の非膨潤性溶媒などで
抽出処理を施し，抽出物和よび不溶性残渣の分析学行な うならば，それによつて，キシラン，マンナンなどの細 胞内に和ける状熊，あるいはそれらがィ゚ルプの性質に和 よ庄す影響などについて，かなりの知見が得られるので はないかと考えられる。このよ5な目的の下に, 吒解比 よるパルプ拈よび木材ホロセルロース中の多䌅類の挙動 について砶究を行なつた。

\section{II. 実 験 法}

\section{1. 吒解姏理}

吅解処理はランペンミルを用いて行なつた。3\% 賑度 のパルプスラリー（絶乾換算 $24 \mathrm{~g}$ ）をランペンミルのケ ース中に入れ，10kg のボールと共に 240 rpm の回転速 度で，叫解時間を 30 分，1，2，5呿よび 10 時間と变古 て吒解した。

吒解パルプはパルプ濃度 $1.2 \%$ としてから Tappi 標 準離解器にて 3 分間離解し，その後，パルプ濃度 $1 \%$ 京 で希釈してから 26G3 のグラスフィルターを用いて欂過 
した。濾過の際, 最初のやや濁つている滤液は反復濾 過して透明な液を得た。残渣は蒸留水で充分に洗浄し た。

\section{2. ハルブの比表面積の測定}

湘定恃 Benzo Fast Scarlet 4BS を用いた染料吸着 法7,8) 亿基ついて行なつた。すなわち, 約 1.3\% 濃度の パルプ分散夜 $250 \mathrm{~m} l に \mathrm{~N} / 10 \mathrm{KCl}$ 溶液 $4 \mathrm{~m} l$ を加兄, 液 温を $25^{\circ} \mathrm{C}$ に保つてから $0.32 \mathrm{~g} / \mathrm{l}$ 濃度の染料溶液を 10 $50 \mathrm{~m} l$ 添加し, 10 分間作用前後の染料の量をべックマン 紫外分光光度計にて比色定量して吸着量を求めた。

3. ハルプのアルカリ溶解度の測定

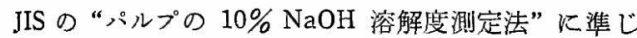
て行なつた。ただしウェットパルプを用いたため，添加 後のアルカリ濃度が試料中の水分を含めて目的の濃度に なるように，添加アリカリ濃度を考虑した。なお液比は 100 (対絶乾試料) で， $20^{\circ} \mathrm{C} ， 1$ 時間の処理を行なつた。

\section{4. 多糖類租成の分析}

パルプ拉よびそのアルカリ溶解物は，それぞれ全加水 分解処理した後, ペーパークロマトグラフィーによつて 糖組成を定量した ${ }^{9,10) 。 ~}$

吒解濾液中の多糖類は，これを $4 \% \mathrm{H}_{2} \mathrm{SO}_{4}$ 濃度で 9 時 間，沸腾湯浴中で加水分解し，同じくペーパークロマト グラフィーによつて定量した。な特，キシランの量は加 水分解の際任生じたメチルグルキュロノキシランの量か らの補正 ${ }^{10)}$

5. 重合度の測定

パルプの重合度測定は硝化法 ${ }^{11)}$ を用い，溶出多糖類の 場合飞法 $10 \% \mathrm{KOH}$ 溶液に溶解 $\left(30^{\circ} \mathrm{C}, 1\right.$ 時間) 後の粘 度をオストワルド粘度計にて測定して求めた ${ }^{12,19) 。 ~}$

\section{III. 実 験 結 果}

\section{1. 印解処理によるパルプのアルカリ溶解度の变化}

カバ材のさらしサルファイトパルプ（製紙用ストロン グ蒸解ペルプ）をアルコール：ベンゼン $(1: 2)$ 溶液で 抽出した後, ランペンミルで 30 分， 1,2 招よび 10 時 間吒解を行ない，得られたパルプの吒解度 (NR) 比表面 積，アルカリ溶解度の測定およびアルカリ溶解物の組成 分析を行なつた。

パルプの吒解度は叨解 10 時間で $95^{\circ} \mathrm{SR}$ にす達し, 比 表面積は第 1 図のよ5 亿叨解時間と共に注活直線的に增 加した。また第 2 図の顕微鏡写真（位相差）によれば， 吒解30分で木瀻維は幾分フィブリル化され，導管は一部 破壊され，吒解 1 時間で外部フィプリル化がかなり進行 し, 10 時間ではほとんど単䋐維の形態を留めないまで にフィブリル化された。

このような吒解処理を受けだ゚ルプをアルカリ抽出す

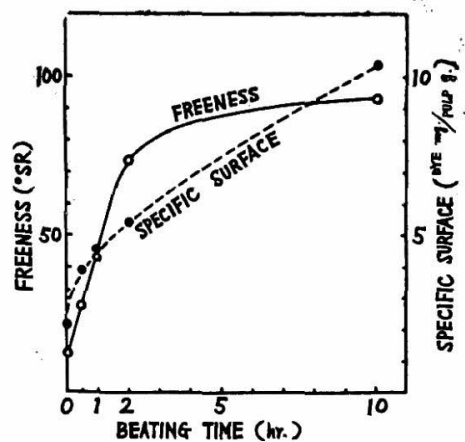

Fig. 1 Increase of specific surface of birch bleached sulphite pulp with the progress of beating. (Lampén mill, at $240 \mathrm{rpm}$, pulp conc. $3 \%$ )

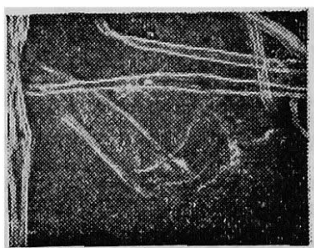

\section{BEATNG TIME}

30 mins.

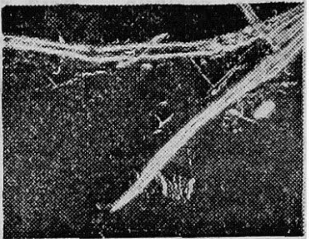

$1 \mathrm{hr}$.

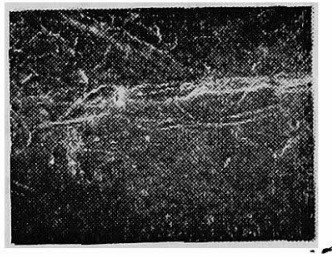

$10 \mathrm{hrs}$.

Fig. 2 Microphotographs of beaten birch bleached sulphite pulp.

る場合には，当然溶解度のかなりの增加が期待される が，結果は予想仅反し，第 3 図の上 び $18 \% \mathrm{NaOH}$ 溶解度は吒解の進むにしたがつてむしろ 低下の傾向を示した。10\% $\mathrm{NaOH}$ 溶解度だけは幾分增加 したが， $10 \% \mathrm{NaOH}$ 溶解物を加水分解した後その組成 を分析した結果, 第 1 表のように增加しているのはグル コース犬゙けで，マンノース，キシロース拉よびウロン酸 量にはほとんど变化がなかつた。

この現象は蒸解度の異なる他の二, 三のパルプについ ても認められた。 


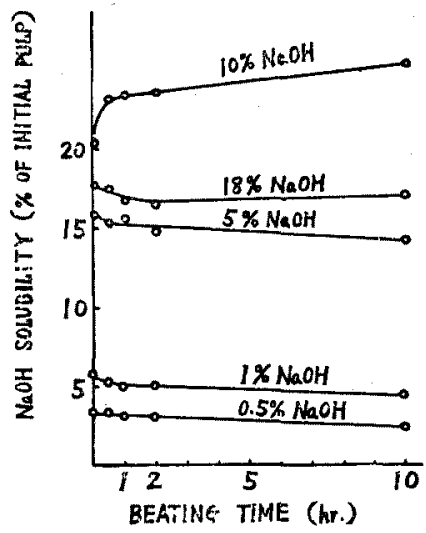

Fig. 3 Change of $\mathrm{NaOH}$ solubilities of birch bleached sulphite pulp with progress of beating.

Table 1 Change of Composition of $10 \% \mathrm{NaOH}$ Soluble Polysaccharide from Birch Bleached Sulphite pulp with progress of Beating.

\begin{tabular}{|c|c|c|c|c|}
\hline \multirow{2}{*}{$\begin{array}{c}\text { Beating } \\
\text { time } \\
\text { hr. }\end{array}$} & \multicolumn{4}{|c|}{$\begin{array}{l}\text { Composition of } 10 \% \mathrm{NaOH} \text { soluble } \\
\text { polysaccharide ( } \% \text { of initial } \mathrm{BSP})\end{array}$} \\
\hline & $\begin{array}{l}\text { xylose } \\
\text { residue }\end{array}$ & $\begin{array}{l}\text { mannose } \\
\text { residue }\end{array}$ & $\begin{array}{l}\text { glucose } \\
\text { residue }\end{array}$ & $\begin{array}{l}\text { methyl glucuronic } \\
\text { acid residue }\end{array}$ \\
\hline 0 & 13.8 & 2. 1 & 1.9 & 0.9 \\
\hline 1 & 13.6 & 2.1 & 4.8 & 1.0 \\
\hline 10 & 13.5 & 2.3 & 7.7 & 0.9 \\
\hline
\end{tabular}

\section{2. 吒解濾液中の多糖類の分析}

以上の上万な結果から，叨解に上つてパルプ中の多糖 数の一部が液中心溶出除去されるのではないかといるこ とが考光られる。

吒解の進行と共に䫏次取り出した吒解液を反復濾過し

Table 2 Polysaccharides extracted from Birch BSP by Beating (Lampén Mill, at $240 \mathrm{rpm}$ )

\begin{tabular}{c|c|c|c|c|c}
\hline $\begin{array}{c}\text { Beating } \\
\text { time } \\
\text { hr. }\end{array}$ & \multicolumn{4}{|c}{ Polysaccharide composition (mg/100g of BSP) } \\
\hline residue & $\begin{array}{c}\text { mannose } \\
\text { residue }\end{array}$ & $\begin{array}{c}\text { glucose } \\
\text { residue }\end{array}$ & $\begin{array}{c}\text { methyl glucuromic uronic unit } \\
\text { acid residue }\end{array}$ & xylose unit \\
\hline 0.5 & 550 & - & - & 61 & $1: 13.0$ \\
1 & 690 & - & - & 75 & $1: 13.2$ \\
2 & 917 & - & - & 106 & $1: 12.5$ \\
10 & 1217 & trace & trace & 135 & $1: 13.0$ \\
\hline
\end{tabular}

Table 3 Carbohydrates Composition of Birch BSP and Holocellulose

\begin{tabular}{l|c|c|c|c|c|c|c}
\hline \multicolumn{1}{|c|}{ Sample } & $\begin{array}{c}\text { xylose } \\
\text { residue } \\
\%\end{array}$ & $\begin{array}{c}\text { arabinose } \\
\text { residue } \\
\%\end{array}$ & $\begin{array}{c}\text { mannose } \\
\text { residue } \\
\%\end{array}$ & $\begin{array}{c}\text { galactose } \\
\text { residue } \\
\%\end{array}$ & $\begin{array}{c}\text { rhamnose } \\
\text { residue } \\
\%\end{array}$ & $\begin{array}{c}\text { methyl glucuronic } \\
\text { acid residue } \\
\%\end{array}$ & $\begin{array}{c}\text { uronic unit/ } \\
\text { xylose unit }\end{array}$ \\
\hline birch BSP & 15.7 & - & 3.1 & - & - & 1.0 & $1: 22.6$ \\
birch holocellulose & 36.0 & 0.8 & 2.9 & 0.8 & 0.25 & 4.3 & $1: 12.0$ \\
\hline
\end{tabular}

て透明な液を得，これを $40^{\circ} \mathrm{C}$ 以下で 20 分の1の容量

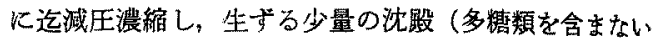
ことがペーパークロマトグラフィーによつて確認された） を遠心分離した。上澄液は更に小容量になるまで謴縮し た後，約 100 倍量のア゙トンを加えた結果，灰白色の沈 殷が得られた。この沈殿物を加水分解した後，絉成分析 を行なつた結果，第 2 表のよ 5 K 10 時間の肮解腹液中 にはパルプに対して $1 \%$ 以上のキシランが認められた が，グルコマンナンははとえど認められなかつた。 表に示したようにかなり多量のメチルグルキュロン酸基 子琵められた。すなわら，吒解で溶出したキシランはい ずれるキシャース残基約 13 ケに対して 1 ケの割合でウ ロン酸基を含んで乱り，用いたBSP（さらしサルフォイ トパルプ）のウロン酸基：キシトース残基 $1: 23$ (第3

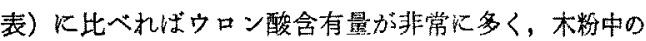
キシランの場合 (1: 12)にほぼ匹敵した。

なお 10 時間印解後の溶出キシランの重合度は 32 で あつた。

\section{3. カバ材のホロセルロースからの溶出多䌅類}

カバ材の薄いかんな屑をアルコール：ベンゼン(1:2) 溶液で抽出した後， $\mathrm{NaClO}_{2}$ で脱りグニンして絃維状小 ロセルロースを筒製し，前と同様ランペンミルで 1〜10 時間の吒解を行ない，溶出多精類の分析を行なつた。

この試料は紻維がかなり㓮直であつたため，吒解の進 行も漣く，多た，糖類の溶出速度る荤かつた。しかし BSP の場合と異り，キシロースとウロン酸の他几，ア ラビノース，マンノース，グルコース，ガラクトース拈

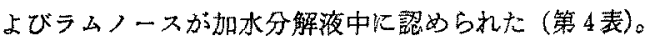
これらの多糖類の中，ラムノース，ガラクトース乩び アラビノースはマンノースに比べてホロセルロ一ス中で の割合が非常に低く(第3表)，ラ ム广一スはマンノース0 10\%以下, ガラクトース就よびアラビノースは いずれも $30 \%$ 以下の量しか占めて いないが，吅解䉥液中でのラムノー ス量はマンノースの $20 \%$ 以上，後 の2者はいずれも約 $50 \%$ 以上と相 対的に多量のbのが溶出している。

溶出された多糖類中のキシロース 残基に対するウロン酸基の割合るホ 
Table 4 Polysacharides extracted from Birch Holocellulose by Beating (Lampén Mill, at $240 \mathrm{rpm}$ )

\begin{tabular}{|c|c|c|c|c|c|c|c|c|c|}
\hline \multirow[b]{2}{*}{$\begin{array}{c}\text { Beating } \\
\text { time } \\
\text { hr. }\end{array}$} & \multirow{2}{*}{$\begin{array}{l}\text { Freeness } \\
\text { og. R. }\end{array}$} & \multicolumn{8}{|c|}{ Extracted polysaccharide } \\
\hline & & $\begin{array}{l}\text { xylose } \\
\text { residue } \\
\mathrm{mg} / 100 \mathrm{~g} \\
\text { of holo- } \\
\text { cellulose }\end{array}$ & $\begin{array}{c}\text { arabinose } \\
\text { residue } \\
" \prime\end{array}$ & $\begin{array}{c}\text { mannose } \\
\text { residue } \\
f^{\prime \prime}\end{array}$ & $\begin{array}{c}\text { glucose } \\
\text { residue } \\
\text { "l }\end{array}$ & $\begin{array}{c}\text { galactose } \\
\text { residue } \\
\prime \prime\end{array}$ & $\begin{array}{c}\text { rhamnose } \\
\text { residue } \\
\prime \prime\end{array}$ & $\begin{array}{c}\text { methyl } \\
\text { glucuronic } \\
\text { acid } \\
\text { residue } \\
" 1\end{array}$ & $\begin{array}{l}\text { uronic unit } \\
\text { xylose unit }\end{array}$ \\
\hline 0 & 7 & & & & & & & & \\
\hline 1 & 10 & 310 & 12 & 20 & 39 & 13 & 4.4 & 65 & $1: 6.9$ \\
\hline 2 & 19 & 470 & 20 & 31 & 50 & 23 & 7.8 & 95 & $1: 7,1$ \\
\hline 5 & 68 & 705 & 24 & 59 & 70 & 25 & 15 & 122 & $1: 8.3$ \\
\hline 10 & 86 & 937 & 30 & 65 & 77 & 36 & 21 & 154 & $1: 8.8$ \\
\hline
\end{tabular}

ロセルロースの場合に比べてかなり高く，叮解初期には キシロース残基 7 ケに対して1ケのウロン酸を含さ多糖 類が溶出し，吅解の進行に伴なつて溶出キシラン中のウ ロン酸の割合は次第に低下した。

以上のことからパルプのキシランのみならず，木材の キシラン中に批けるゥン酸の分布はかなり不規則であ り，叨解処理などによつてこれらの多糖類と水との接触 が盛んになると，ウロン酸含㻎が高く水との親和性の強 いキシランから，徐ヶK溶出されて行くようである。

なお，10時間の叨解によつて溶出した，キシランを 主とする多粒類の重合度を測定した結果 91 の犆を得た。 この值は通堂の木材中のキシランの重合度 (100 2002,14) ) よりたいして低くはない。この結果から当前 に速べた BSP からの溶出キシランの重合度 32 がかり 蚳い值でるり，蒸解，漂白処理によつてパルプ中のキシ ランが相当な崩壊作用を受けていることがわかる。

4. 叮解処理によるトト松 BSP からの溶出多糖類

第5表の組成を有するトド松 BSP を同様に叮解した 結果は第 6 表の通りて，溶出多精類のウロン酸基/キシ ロース残基の割合は，パルプの場合の平均值に比べて僅 加高い程度であつた。

ただし，このパルプには多量のマンナン（グルコマン ナン)が合をれているにもかか放らず,吅解によつてかチ ルグルキュロノキシランだけしか溶出しなかつたことは
Table 5 Carbohydrates Composition of Fir (Abies Mayriana) Bleached Sulphite Pulp

\begin{tabular}{|c|c|c|c|}
\hline $\begin{array}{c}\text { Xylose } \\
\text { residue } \\
\%\end{array}$ & $\begin{array}{c}\text { Mannose } \\
\text { residue } \\
\%\end{array}$ & $\begin{array}{c}\text { Methyl glucuronic } \\
\text { acid residue } \\
\%\end{array}$ & $\begin{array}{l}\text { uronic unit/ } \\
\text { xylose unit }\end{array}$ \\
\hline \multirow[t]{2}{*}{4.7} & \multirow[t]{2}{*}{7.5} & $1.25\left(\begin{array}{l}\text { paper chro- } \\
\text { matography }\end{array}\right)$ & 1.54 \\
\hline & & 1.17 ( $\mathrm{CO}_{2}$-method $)$ & $1: 5.8$ \\
\hline
\end{tabular}

興味深い。このことは, Immergut および Rånby'15) が スプルースの BSP $17.8 \% \mathrm{NaOH}$ 溶没で抽出して, 抽出物を $\beta ， \gamma_{1} ， \gamma_{1(2)} ， \gamma_{2}$ 特よび $\gamma_{3}$ に分别した際，最 も水溶性のフラタションにがり多量のグルコマンナン

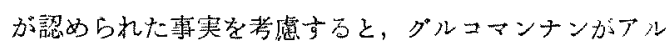
カリによつて非常化低分子化して水に溶け易くなるか， または、マンナンはキシランよりも細胞膜の比較的内部, または結晶部化存在していることを示している。

\section{IV. 総括}

カバ材 BSP をランペンミルで解すると,メキルダ ルキュロノキシランだけが吒解液中に溶出した。

カバ材ホロセルロースの場合炕はこの他に，ラム， 一ス,アラピノース,ガラクトース、、ンノース执よ゙グ ルコースを含む多糖類が叨解液中に見出だされたが，殊 に前 3 者の溶解性が高い上うである。きたいずれの場合 でも，溶出キシランのウロン酸含有量はかなり高く、こ

Table 6 Polysaccharides extracted from Fir BSP by Beating

(Lampén Mill, at 240rpm)

\begin{tabular}{|c|c|c|c|c|c|c|}
\hline \multirow[b]{2}{*}{$\begin{array}{c}\text { Beating } \\
\text { time } \\
\text { hr. }\end{array}$} & \multirow{2}{*}{$\begin{array}{c}\text { Freeness } \\
\text { os. R. }\end{array}$} & \multicolumn{5}{|c|}{ Extracted polysaccharide } \\
\hline & & $\begin{array}{l}\text { zylose } \\
\text { residue } \\
\mathrm{mg} / 100 \mathrm{~g} \\
\text { of } \mathrm{BSP}\end{array}$ & $\begin{array}{c}\text { mannose } \\
\text { residue } \\
\end{array}$ & $\begin{array}{c}\text { glucose } \\
\text { residue } \\
n\end{array}$ & $\begin{array}{c}\text { methyl glucuronic } \\
\text { acid residue } \\
\end{array}$ & $\begin{array}{l}\text { uronic unit/ } \\
\text { xylose unit }\end{array}$ \\
\hline $1 / 3$ & 24 & 227 & - & - & 69 & $1: 4.7$ \\
\hline 1 & 49 & 275 & - & - & 76 & $1: 5.2$ \\
\hline 5 & 91 & 443 & trace & trace & 122 & $1: 5.2$ \\
\hline
\end{tabular}


のことからカバ材怙よびカバ材パルプのキシラン中に話 けるメチルグルキュロン酸基の分布の不規則性, お上び キシランのウロン酸含有量とそれらの水に対する溶解性 との関係を指摘した。

トト松の肮解の場合にも、メチルグルキュロノシラン だけしか溶出しないことから，ダルコマンナンとキラン とのアルカリ抵抗性，または分布状態の羑を推察した。 本研究に際し御指導を賜わつた東京大学農学部右田伸 彦教授，国策パルプ工業株式会社軒原栄三博士，並びに 実駼に協力された浜田忠平君に深く感謝する。

本報告の要旨は 1958 年 5 月瀻維学会講演会で発表し た。

\section{文献}

1) D. A. Sitch, H. B. Marshall ; Can. J. Res., 28,376 (1950)

2) 今村力造；緎学誌，8，539（1952）

3) 右田伸渗, 神田孝, 佐藤修一, 小島莘雄；樴学誌, 12, 14 (1956)

4) L.E.Wise ; Paper Ind., 37, 1024 (1956)

5) H.Sadler, O.Trantina; Das Papier, 10, 459 (1956)
6) H.W. Emerton ; Fundamentals of the Beating Process, p. 79-117 (1957)

7) J.W. Beamesderfer, E. F. Thode, A.J. Chase, R.E. Hubbard ; Tappi, 35, 374 (1952)

8) E.F.Thode, J. W. Beamesderfer, A. J. Chase ; Tappi, 35, 379 (1952)

9）戸田久昭，浜田忠平；技協誌，12，No. 5, 324 (1958)

10） 戸田久昭；本誌，16，725（1960)

11）浅岡宏，鉿木彰，工藤耕一; 工化，59，No. 2, 161 (1956)

12) J. O. Thompson, L.E. Wise ; Tappi, 35, 331 (1952)

13) L. P. Clermont ; Pulp Paper Mag. Can., 56, No.11, 107 (1955)

14）例えば

M. Horio, R. Imamura, H. Inagaki ; Tappi, 38, 216 (1955)

浅岡宏，佐藤二郎；紙分技協誌，11，634 (1957)

15) B. Immergut, B. G. Rånby ; Svensk Papperstidn., $60,573(1957)$

（注）本研究を“木村叔よびパル中の多糖類に関する 研究第 5 報”とする。 